\title{
同極性合体を用いて生成された各種球状トーラスの 磁束緩和に関する比較研究
}

\author{
正員 鶴田 蔛子* 正員 小野 靖* \\ 正員 桂井 誠*
}

\begin{abstract}
Comparative Studies on Magnetic Flux Relaxations of Varied Spherical Toroids
Produced by Co-helicity Merging
\end{abstract}

Mayuko Tsuruda*, Member, Yasushi Ono*, Member, Makoto Katsurai*, Member

\begin{abstract}
The co-helicity merging operations of compact toroid(CT) and spherical tokamak(ST) have been performed with external toroidal field in the CT/ST merging device TS-4. The low-q(safety factor) CT mergings as the compact RFP merging and the spheromak merging show the flux conversion from toroidal to poloidal in the course of the reconstruction of the Taylor force free state. The relaxation to the Taylor state proceeds through the following three states; (1)axisymmetric merging with increasing toroidal flux, (2)increase in the poloidal flux $\Psi$ and, (3)relaxation to the Taylor state. The high-q ST merging shows different relaxation process from those of the compact RFP and the spheromak mergings. Increases in $\Psi$ were not clearly observed in the ST merging. The measured eigen values $\lambda$ show that ST's, especially high-q ST's, approach a unique intrinsic equilibrium state that has a $\lambda$ proportional to $\Psi$ with a longer lifetime than that of CT's. When external toroidal field is set in a certain range between the low-q operation and the high-q operation for ST's, an abnormal phenomenon was found in the ST formation, namely, a drastic decrease in the plasma lifetime. This phenomenon is characterized by very week poloidal flux generations during the initial plasma production phase and the subsequent plasma separation phase when the plasma starts detaching from the flux-core.
\end{abstract}

キーワード：球状トーラス, プラズマ合体 , スフェロマク , 球状トカマク , フラックスコア

Keywords: spherical torus, plasma merging, spheromak, spherical tokamak, flux core

\section{1.はじめに}

熱核融合エネルギー開発研究の一環である磁気閉じ込め プラズマ研究において，従来のトカマク方式と同じく軸対 称内部電流系方式である球状トーラスと呼ばれる一連の配 位が注目されてきている。球状卜ーラスとは，トカマク方 式と比較して低アスペクト比 (大半径/小半径 $\leq \sim 1.6$, 卜 カマクでは 3 程度) のトーラスプラズマのことをいい , 小型 高効率な閉じ込めが期待されている。具体的な磁界構造と しては, テーラー平衡状態 (付録参照) にあると考えられる スフェロマク , コンパクト逆磁場ピンチ (コンパクト RFP) などのコンパクトトーラス $(\mathrm{CT})$, およびテーラー平衡ま で緩和していないと考えられる球形トカマク $(\mathrm{ST})$ などが

\footnotetext{
* 東京大学

T 113-8656 東京都文京区本郷 7-3-1

University of Tokyo

7-3-1, Hongo, Bunkyo-ku Tokyo 113-8656
}

ある。

これら球状トーラス核融合炉の実用化を考えたとき，プ ラズマ生成部と閉じ込め部を分離し，かつ小規模なプラズ マ生成部を用いて所定の大きさの炉心プラズマを生成する 手法として ,プラズマの同極性合体が提案されている。図 1 にプラズマ同極性合体の概念図を示す。図のように二つの 球状卜ーラスを軸対称性を保ったまま合体させると原理的 には合体終了後, 合体前のへリシティ総和に相当するへリ シティを持った同種の単体球状トーラスが生成される。こ のようなプラズマ合体を繰り返すことにより所定の大きさ になるまでプラズマを肥大化させることが考えられる。

この合体においては, 軸対称性と完全導体性を仮定する と, 磁束の保存則から同一のポロイダル磁束を持った磁気 面が外側より逐次合体する。よって合体前後のトロイダル， ポロイダル両磁束の総量に関して以下の関係式 (1) が成り 立つ ${ }^{(1)}$ 。 


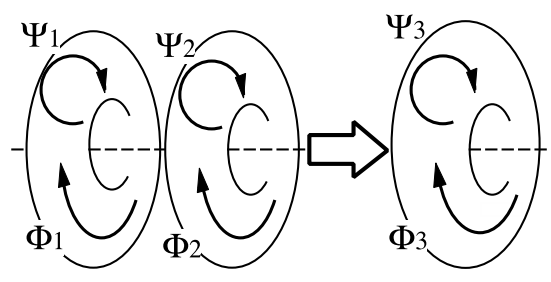

図 1 同極性合体

Fig. 1. Co-helicity merging.

$\left.\begin{array}{l}\text { トロイダル総磁束 } \Phi: \Phi_{3}=\Phi_{1}+\Phi_{2} \\ \text { ポロイダル総磁束 } \Psi: \Psi_{3}=\max \left(\Psi_{1}, \Psi_{2}\right)\end{array}\right\} \cdots$

このとき合体する二つのプラズマが同規模とすると $\Psi_{3}=$ $\Psi_{2}=\Psi_{1}=\Psi$ となる。また，内部の磁界分布については 以下の安全係数 q についての関係が成りたつ。

安全係数 $q: q_{3}(\Psi)=q_{1}(\Psi)+q_{2}(\Psi)$

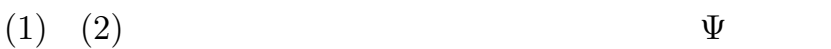
ては合体前と変わらず， $\Phi$ にいては和となるため，テー ラー状態に対して $\Phi$ が過剩となることがわかる。

テーラー平衡配位であるコンパクト RFP やスフェロマ クでは合体生成配位は $\Phi$ が過剩な状態から緩和を始め，自 己組織化現象により再び $\Psi$ と $\Phi$ はテーラー平衡のもとで バランスがとれた状態になると考えられており，この推察 について実験的証明が必要である。一方, テーラー平衡状 態までは緩和していないといわれる ST では , 合体による 過剩な $\Phi$ を有する状態からの緩和特性については未解明で ある。

本研究では将来の合体炉心プラズマ生成を想定して合体 手法の適用を念頭に，各種球状卜ーラスについてこのよう な磁束緩和現象の特性を解明することを目的としている。 合体生成されたプラズマは，合体前のプラズマの総磁気工 ネルギーの一部を加熱エネルギーとして受け取る ${ }^{(2)}$ 。しか し，この加熱効果については本論文では直接測定は行って おらず課題としては取り上げていない。

\section{2. 実験装置}

図 2(a) に本研究で用いたプラズマ合体実験装置 TS-4の 側面図および，(b)に磁気計測結果より得られたスフェロ マク合体の樣子 ( $\Psi$ の等磁気面の時間変化) を示す。

TS-4 装置は平衡磁界コイル (EF コイル) およびフラッ クスコアを用いた誘導方式 ${ }^{(3)}$ による二つのプラズマ生成部 を持ち，光れ等によって二つのプラズマを弚れ独立に 生成することができる。また，中心軸に沿って設置された 中心導体アセンブリーに内蔵された外部卜ロイダル磁界コ イルの電流 $I_{t f c}$ によって外部トロイダル磁界を変化させ， 生成プラズマの安全係数 (q 值) 制御が可能である。これに よって単一装置内において逆磁場ピンチ (RFP), スフェロ マク, 球形卜カマク $(\mathrm{ST})$ を弚れ生成することができ る。TS-4 装置では关の設計上, 生成されるプラズマのア

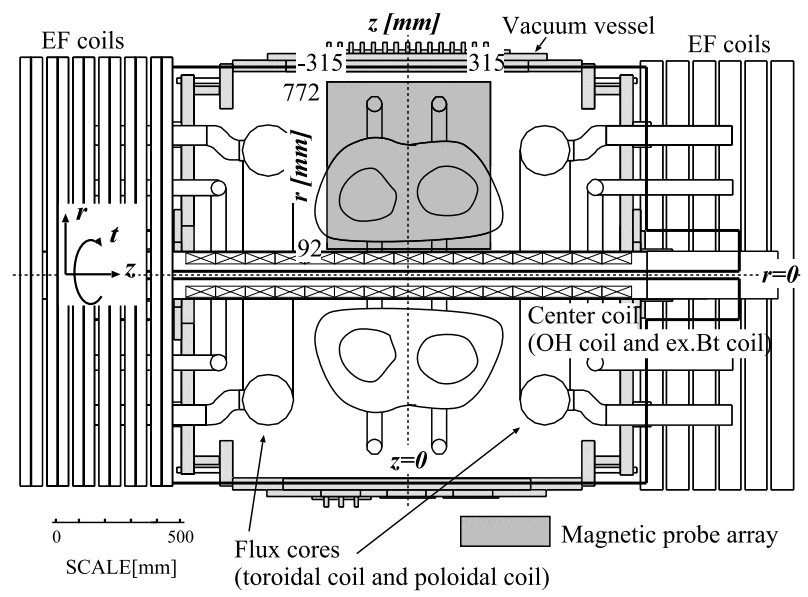

(a) TS-4 device

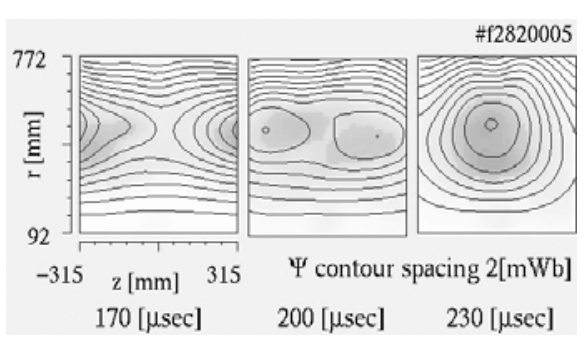

(b) $\Psi$ contours reconstructed by magnetic probe array (spheromak merging)

图 2 プラズマ合体実験装置 TS-4

Fig. 2. Merging experimental device TS-4.

スペクト比は $\mathrm{A}=1.2 \sim 1.3$ 程度になる。乥こで TS-4 装 置における RFP をここではコンパクト RFP と呼ぶこと にする。TS-4 装置の詳細については別報に説明されてい $ろ^{(4)(5)}$ 。

本研究における計測系は磁気プローブアレーによる磁気 計測が中心である。図 2 に磁気計測範囲を同時に示す。磁 気プローブアレーの測定範囲は半径方向に中心導体アセン ブリー表面 $\mathrm{r}=92[\mathrm{~mm}]$ から $\mathrm{r}=772[\mathrm{~mm}]$, 装置中心を $\mathrm{z}=0$ として軸方向に $\mathrm{z}= \pm 315[\mathrm{~mm}]$ の間の領域であり，トロイ ダル磁界 $B_{t}$, 軸方向磁界 $B_{z}$ の 2 方向について兰れ先れ半 径方向に 10 点, 軸方向に 7 点の計 140 測定点から成る。 の 2 次元の磁界計測値から軸対称性を仮定して各物理量を 以下の式によって算出する。すなわち磁気面関数 $\Psi$ は

$$
\Psi(r, z)=\int_{r_{\text {min }}}^{r} B_{z}(r, z) 2 \pi r d r \ldots \ldots \ldots \ldots \ldots
$$

ここで $r_{\min }$ は中心導体アセンブリーの外半径であり，光 の円筒表面において $\Psi=0$ と仮定されている。また , アン ペアの法則 $\mu_{0} \boldsymbol{j}=\nabla \times \boldsymbol{B}$ から電流密度 $\boldsymbol{j}$ は

$$
\begin{aligned}
& j_{t}=\frac{1}{\mu_{0}}\left(\frac{\partial B_{z}}{\partial r}-\frac{\partial B_{r}}{\partial z}\right) \\
& j_{z}=\frac{1}{\mu_{0}}\left(\frac{1}{r} \frac{\partial\left(r B_{t}\right)}{\partial r}-\frac{1}{r} \frac{\partial B_{r}}{\partial \theta}\right)=\frac{1}{\mu_{0} r} \frac{\partial\left(r B_{t}\right)}{\partial r}
\end{aligned}
$$

よってプラズマ電流 $I_{p l a}$ は 


$$
I_{p l a}=\int_{S} j_{t} d z d r \ldots \ldots \ldots \ldots \ldots \ldots \ldots \ldots \ldots
$$

またテーラー無力磁界配位 $\mu_{0} \boldsymbol{j}=\lambda \boldsymbol{B}(\lambda$ は空間的に一樣 $)$ の固有値 $\lambda$ に関して，実測値としては以下の $\lambda_{p}$ で代替す る。 $\lambda_{p}$ はポロイダル方向のテーラー平衡 $\mu_{0} j_{z}=\lambda_{p} B_{z}$ を 仮定することにより次式で求まり，付録に記すように磁気 面上で $\lambda$ は一定であることから $\lambda_{p} \sim \lambda$ と考えられる。

$$
\lambda_{p}=\frac{\mu_{0}}{\Psi} \int_{r_{\min }}^{r} j_{z} 2 \pi r d r=\frac{2 \pi r B_{t}}{\Psi} .
$$

TS-4 装置ではさらにトロイダルモードの計測を行っ ている。測定点は 8 点で半径方向 $\mathrm{r}=294.5[\mathrm{~mm}]$, 軸方向 $\mathrm{z}=77[\mathrm{~mm}]($ 装置中央が $\mathrm{z}=0)$ に設置されており，トロイダ ルモード $\mathrm{n}=1,2,3,4$ の計測が可能である。

\section{3. 実験結果}

〈3.1 1 実験範囲图 3 に外部卜ロイダル磁界コイル 電流 $I_{t f c}$ の変化による合体生成および単体生成された配位 のプラズマ寿命 $\tau$ および平衡磁界強度 $B_{z, e x}$ ，プラズマ電 流 $I_{p l a}$ の変化を弚れ光れ示す。

ここでプラズマ寿命 $\tau$ は, 単体生成の場合には計測範囲 における $\Psi$ の最大値，合体生成の場合には合体直後の $\Psi$ の值から弚の $e^{-1}$ 倍の $\Psi$ になるまでの時間と定義する $(\Psi$ が時間 $t$ に対し $e^{-\frac{t}{\tau_{d}}}$ で減衰するとき, $\tau$ は減衰時定数 $\tau_{d}$ と等しくなる。しかし，途中で不安定が発生すると $\tau<\tau_{d}$ となる)。

また, 平衡磁界強度 $B_{z, e x}$ は平衡磁界コイル (図 $2(\mathrm{a})$ の EF coil) が磁気軸付近に作る磁界強度であり，光の值は平 衡磁界コイルの電流值から算出している。なお，图 3 にお いてフラックスコアの励磁条件は同一であり， $B_{z, e x}$ の変 化は $I_{t f c}$ が異なった場合でも磁気軸位置が時間的に一定と なるように調整した結果である。ただし， $B_{z, e x}$ の值は電 源の仕樣上，およ光 $0.072[\mathrm{kG}]$ が下限值である。

外部卜ロイダル磁界コイル電流 $I_{t f c}$ は , フラックスコア が生成するプラズマ内部のトロイダル磁界と逆向きの場合 を負，同じ向きの場合を正としてある。よって $I_{t f c}$ が負のと きは RFP 配位, $I_{t f c}$ が 0 のときはスフェロマク配位, $I_{t f c}$ が正のときは ST 配位が生成される。図中, 白丸は合体生 成, 黑丸は単体生成を表すが, 単体生成については ST の み安定に生成することができたので光の場合について示す。

图 3 より $I_{t f c}>\sim-8[\mathrm{kAT}]$ において合体生成されたコ ンパクト RFPは，同条件で生成されたスフェロマクと同 程度の寿命を持ち， $I_{t f c}$ が-8 $[\mathrm{kAT}]$ より負方向に大きくな ると, 生成されるプラズマの電流 $I_{p l a}$ および $\tau$ が急激に減 少することがわかる。

一方， $I_{t f c}>\sim 20[\mathrm{kAT}]$ の ST では, $I_{t f c}$ は大きいほど $\tau$ も延び，コンパクト RFP およびスフェロマクと比較す ると最大で 3 倍程度の寿命を持つ。

また , $0<I_{t f c}<\sim 10[\mathrm{kAT}]$ の STは, $I_{t f c} \sim 5[\mathrm{kAT}] て ゙$ $\tau$ の極大值を持つ。この領域における $\mathrm{ST}$ は, $I_{p l a}$ は $30[\mathrm{kA}]$

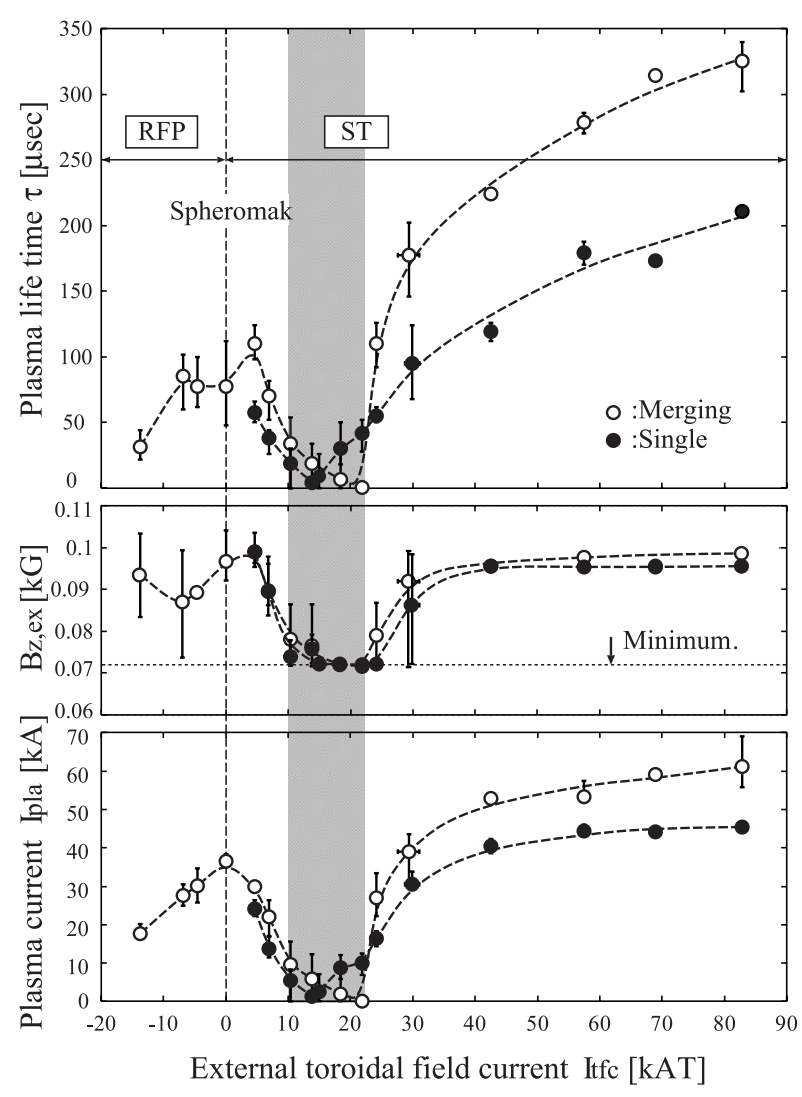

図 3 プラズマ寿命の外部卜ロイダル磁界依存性

Fig. 3. Dependence of plasma decay time on external toroidal field.

前後とスフェロマクやコンパクト RFP とほぼ同程度であ るが，卜カマク特有の安定化効果を示し， $\langle 3 \cdot 3\rangle$ 節に後述す るように比較的トロイダルモードが抑制される。このため， $\tau$ は $\Psi$ の減衰時定数 $\tau_{d}$ にほぼ一致する。

最後に注目すべき現象の一つとして， $I_{t f c}=10 \sim$ $20[\mathrm{kAT}]$ の範囲において生成される ST では, 合体生成， 単体生成にかかわらず $\Psi$ およひ寿命の急激な減少が観測さ れた。これについては〈3・4〉節にて説明する。

〈3. 2〉 テーラー平衡配位の場合: $\Psi$ の増加 テーラー 平衡配位としてはコンパクト RFP およびスフェロマクが 挙げられる。ここでは特に合体効果が磁界構造の変化とし て比較的明解に観測されるコンパクト RFP の場合につい て主に述べる。

図 4 にコンパクト RFP の同極性合体前後における $\Psi$ お よびトロイダルモードの時間発展を示す。ここで $\Psi_{1}, \Psi_{2}$ は左右のフラックスコアによって生成された合体前の配位 弚れ光れのポロイダル磁束の総量， $\Psi_{3}$ は合体過程において すでに再結合したポロイダル磁束の総量である。図中， $\Psi_{1}$ ， $\Psi_{2}, \Psi_{3}$ 全てが一致する $218[\mu \mathrm{sec}]$ が合体完了時と考えら れる。

図 4 の $\Psi$ の時間発展より合体中 $210[\mu \mathrm{sec}]$ より $\Psi$ が増 加を始め，合体後の $224[\mu \mathrm{sec}]$ に極大值を持つことがわか る。このような合体中から合体後にかけての $\Psi$ の増加は， 
同じくテーラー平衡配位であるスフェロマクの同極性合体 時にも見られる。この合体の際に生じる $\Psi$ の増加は , 合体 効果に起因する過乘な $\Phi$ からの磁束変換を介したテーラー 緩和と考えており，この場合， $\Psi$ の増加に対して $\Phi$ の減少 が観測されると期待される。しかし $\Phi$ に関しては，現在の 計測範囲では合体前のプラズマついて計測することが不可 能であるため確認はされていない。

この $\Psi$ の増加に関しては図 4のトロイダルモードの時間

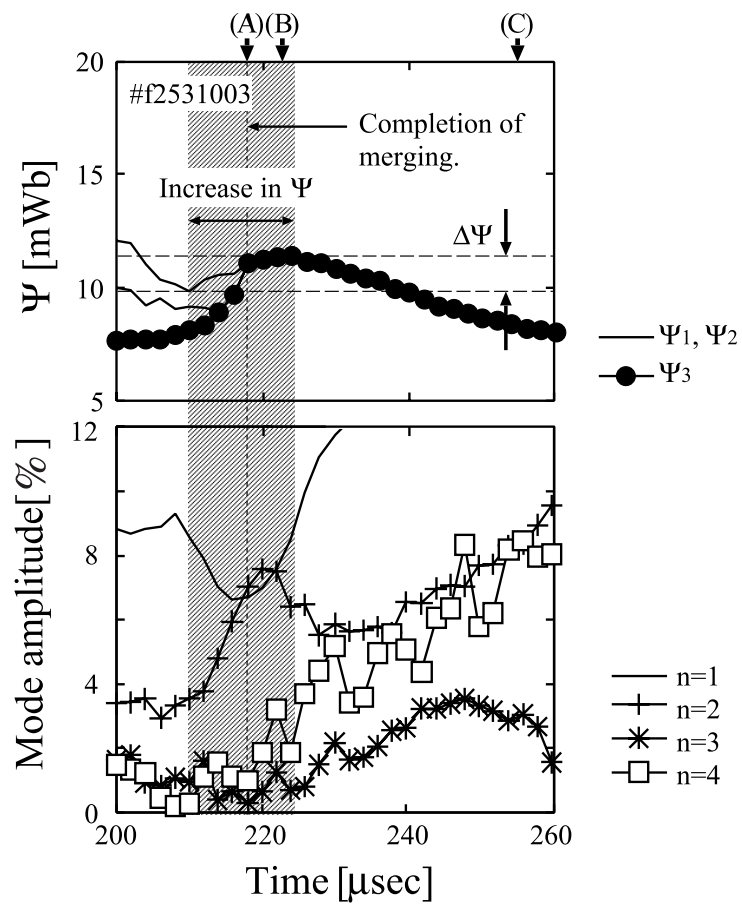

图 4 コンパクト RFP 合体時の $\Psi$ およびトロイ ダルモードの変化 $\left(I_{t f c}=-4.6[\mathrm{kAT}]\right)$

Fig. 4. Time evolution of $\Psi$ and toroidal modes during compact RFP merging $\left(I_{t f c}=-4.6[\mathrm{kAT}]\right)$.
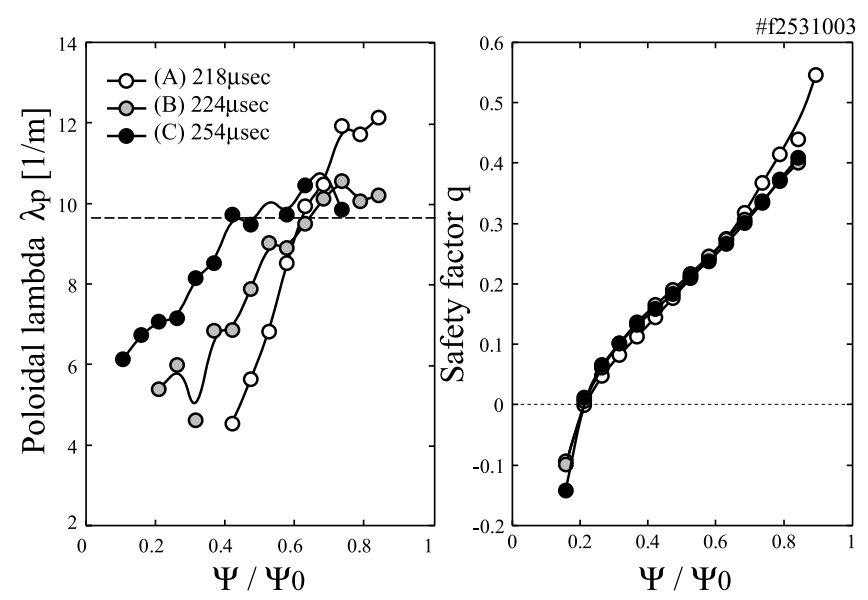

図 5 コンパクト RFP 合体後の $\lambda_{p}$ および $\mathrm{q}$ 値 空間分布の時間発展

Fig. 5. Time evolution of spatial profiles of $\lambda_{p}$ and q-value after compact RFP merging.
発展から， $\Psi$ の増加に合わせて $\mathrm{n}=2$ トロイダルモードの増 加が見られる。このことから，この $\Psi$ の増加に関する主要 な磁束变換機構 (ダイナモ) は $\mathrm{n}=2$ 卜ロイダルモードであ ると推測される。 $\Psi$ の増加時に観測される $\mathrm{n}=2$ トロイダ ルモードの増加は，コンパクト RFP の場合に明快に現わ れるが, スフェロマクの場合には比較的小さく, 複数モ一 ドの増大として現われることも多い。

図 5 に図 4 の合体過程における緩和の樣子を示す。図 5 は図 4 の各時点における $\lambda_{p}$ および q 值の内部空間分布で

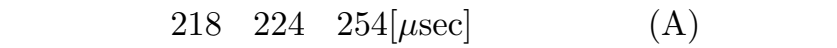
時点, (B) $\Psi$ か増加し最大值となった時点, および $(\mathrm{C})$ テー ラー平衡したと思われる時点の分布を表わしている。

図 5 から合体完了直後の時刻 $218[\mu \mathrm{sec}](\mathrm{A})$ では, 磁気 軸 $\left(\Psi / \Psi_{0}=1\right)$ 付近における $\lambda_{p}$ および q 值が磁気軸周辺 で大きな值を示しており，軸対称合体効果によって磁気軸 付近のトロイダル磁束が増加していると推定される。次に，

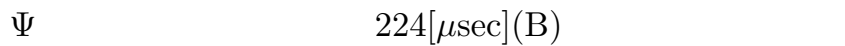
磁気軸付近における $\lambda_{p}$ および q 值が減少することがわか る。ただし，この時点における $\lambda_{p}$ は $\Psi$ に関して一定では なく，まだテーラー平衡していない。光の後， $\lambda_{p}$ は $\Psi$ に関 して磁気軸周辺から徐々に一定となり，時刻 $254[\mu \mathrm{sec}](\mathrm{C})$ ではプラズマの周辺部を除いた $\Psi / \Psi_{0}>0.4$ の領域におい てテーラー平衡の近くまで緩和している。

また q 值に関しては $224 \sim 260[\mu \mathrm{sec}]$ において磁気軸付近 において $0.3 \sim 0.4$ となり, 通常のアスペクト比の RFPよ りも遥かに高い $\mathrm{q}$ 值を示しており, 同配位についての平衡 理論から予想される結果と一致する ${ }^{(6)}$ 。

以上より，コンパクト RFP に代表されるテーラー平衡 配位の場合，式 (1)の合体による $\Phi$ の増加に付随して $\Psi$ の 増加が起こり, 再びテーラー平衡状態へと緩和することが 確認され，結論として合体によるプラズマの肥大化効果が 確認された。

〈3.3〉球形卜 カマクの場合次に, テーラー平衡ま で緩和していない配位といわれる ST について合体による 効果について実験的に検証した。

図 6 は , コンパクト RFP に対する図 4 同樣，ST の同極 性合体前後における $\Psi$ およびトロイダルモードの時間発展 を示したものである。ここで $\Psi_{1}, \Psi_{2}, \Psi_{3}$ の定義は図 4 に ならう。

まず，図 6 のトロイダルモードの時間発展から図 4 のコ ンパクト RFP の場合と比較してトロイダルモードが全体 的に小さいことがわかる。これはすでに述べたように内部 トロイダル磁界と同方向に印加された外部卜ロイダル磁界 によって ST ではトロイダルモードが安定化されるためで あると考えられる。また，合体に関しては ST ではコンパ クト RFP の場合と比較して合体による $\Psi$ の増加は小さく， また合体の際に特定のトロイダルモードの上昇も見られな いことが観測される。

合体による $\Psi$ の増加に関するテーラー平衡配位および $\mathrm{ST}$ の比較を図 7 に示す。コンパクト RFP からスフェ 
ロマク, ST と $I_{t f c}$ を変化させ , ここで合体における $\Psi$ の増加率 $\Delta \Psi / \Psi$ は, 合体終了までの $\max .\left(\Psi_{1}, \Psi_{2}\right)$ の最 小值 $\Psi_{\min }$ と合体終了後の最大值 $\Psi_{\max }$ から $\Delta \Psi / \Psi=$ $\left(\Psi_{\max }-\Psi_{\min }\right) / \Psi_{\min }[\%]$ として定義している。なお图中， $\mathrm{ST}$ 側の $I_{t f c}=10 \sim 20[\mathrm{kAT}]$ (斜線の領域) はすでに述べ たように正常な配位を生成できない領域である。

图 7 よりテーラー平衡配位であるコンパクト RFP および スフェロマクでは比較的高い $\Delta \Psi / \Psi$ を示すのに対し，ST では外部トロイダル磁界の強弱にかかわらず $\Delta \Psi / \Psi$ が全 般的に小さいことがわかる。

また図 7 から，STでは合体に際して生じる過剩な $\Phi$ か

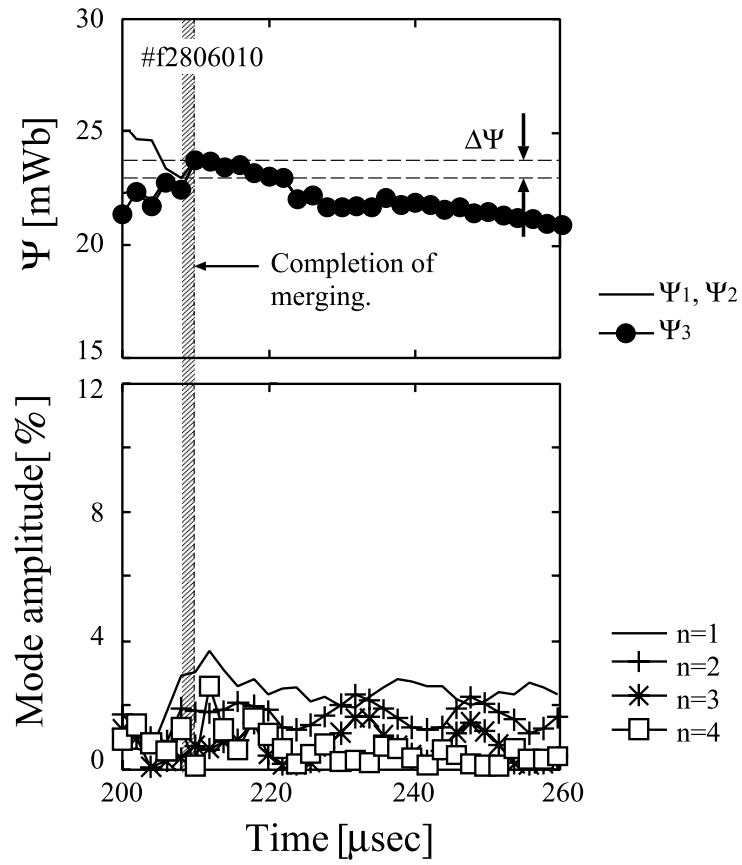

図 $6 \mathrm{ST}$ 合体時の $\Psi$ およびトロイダルモードの 変化 $\left(I_{t f c}=83[\mathrm{kAT}]\right)$

Fig. 6. Time evolution of $\Psi$ and toroidal modes during ST merging $\left(I_{t f c}=83[\mathrm{kAT}]\right)$.

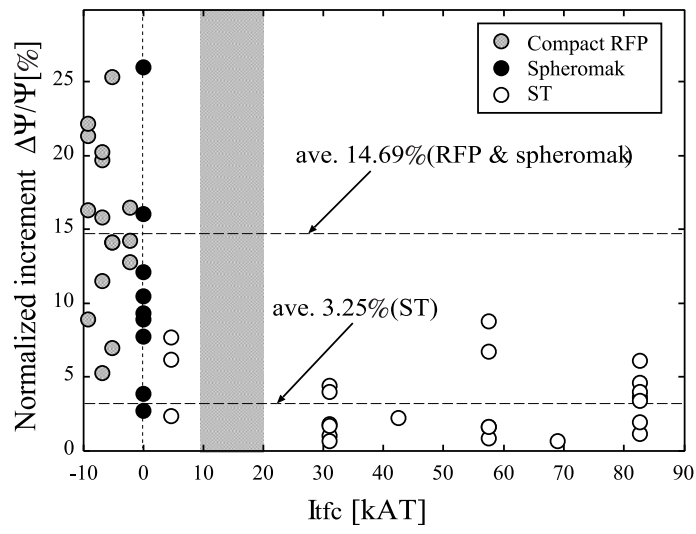

図 7 合体配位による合体直後の $\Psi$ 増加率の違い Fig. 7. Difference of increase in $\Psi$ by CT variations.
らの磁束変換が起こっていないか，起こっていたとしても 小さいことが示唆される。光こで合体効果による平衡状態 の変化をみるために，图 8 に合体および単体生成 ST の $\lambda_{p}$ 分布の比較を示す。ただし，合体および単体生成配位 の全域が計測範囲に収まり, $\lambda_{p}$ 分布が安定した時刻とし て $I_{t f c}=4.6[\mathrm{kAT}]$ では $240[\mu \mathrm{sec}], I_{t f c}=83[\mathrm{kAT}]$ では $350[\mu \mathrm{sec}]$ とした。

図 8 の外部トロイダル磁界が強い場合 $\left(I_{t f c}=83[\mathrm{kAT}]\right)$ では，合体および単体生成による $\lambda_{p}$ 分布の違いは小さい ことがわかる。これは強い外部トロイダル磁界に対し合体 時の過剩な $\Phi$ 影響が相対的に小さいためで，よってこの 場合には, 磁界構造の变化という意味では合体効果の影響 は小さいと考えられる。また, $\lambda_{p}$ 分布は $\Psi$ に対し磁気軸 付近で最大值を持ち, 端部でほぼ 0 の $\Psi$ に比例する特性を 有する。このことから外部トロイダル磁界が強い場合には テーラー平衡状態には緩和していないことが確認された。

図 8 の外部トロイダル磁界が弱い場合 $\left(I_{t f c}=4.6[\mathrm{kAT}]\right)$ では，単体生成の場合， $\lambda_{p}$ は $\Psi$ に対して変化は小さく， テーラー平衡に近い分布となっていることがわかる。一方， 合体生成では, 外部卜ロイダル磁界が強い場合に類似した 磁気軸付近に最大值を持つ $\lambda_{p}$ の分布が形成されているこ とがわかる。この磁気軸付近に最大值を持つ分布は合体に よる $\Phi$ の増加によって形成されると考えられ，图 7 に示す ように ST では $\Psi$ への磁束変換が小さく, 图 5 と異なり， $240[\mu \mathrm{sec}]$ においても分布は弚のまま維持されることが観 測された。これは ST では外部卜ロイダル磁界が弱い場合 でも，テーラー平衡近くまで緩和せずに合体による加熱効 果 ${ }^{(2)}$ を維持できることを示していると考えられる。

図 9 は外部トロイダル磁界の弱い場合 $\left(I_{t f c}=4.6[\mathrm{kAT}]\right)$ における単体および合体時の $\Psi$ の時間変化である。合体が 完了した時点から単体，合体乥れ艺れの場合についての線 形近似を示してある。ただし磁束の減衰率は乥の断面積に 反比例することから，単体生成の近似直線は $\Psi$ の最大值か ら乥の $20 \%$ までに含まれる領域 $S_{\Psi_{20}}$ をプラズマ断面積と して合体生成の場合とのサイズ比に起因する減衰率を補つ てある。ここでプラズマ断面積を $S_{\Psi_{20}}$ としたのは，合体

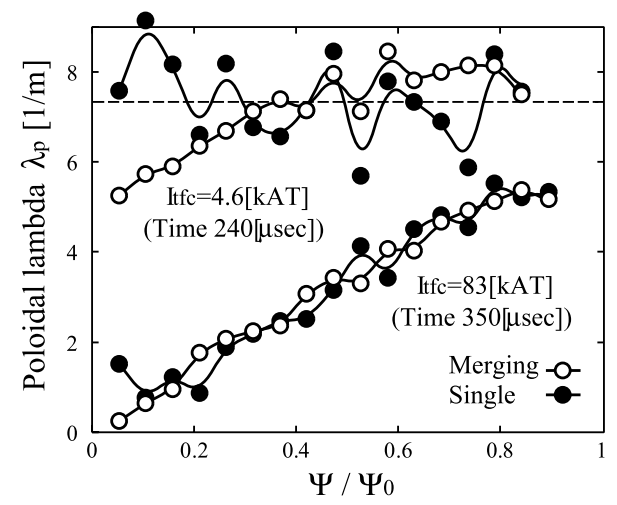

图 $8 I_{t f c}$ の違いによる $\lambda_{p}$ 空間分布の比較 Fig. 8. Comparison of $\lambda_{p}$ with different $I_{t f c}$. 
生成の場合， $\Psi$ が最大となる合体直後においてプラズマ全 体が計測範囲に収まる範囲に限定したことによる。

図 9 から合体時の方が単体時と比較して，寸法効果以上 に $\Psi$ の減衰率が小さく，電子温度の上昇が予想される。合 体生成では，対象となるプラズマは，合体するプラズマの エネルギーを磁気エネルギーの他に兴の一部を加熱エネル ギーとして受け取る。図 9 より，ST では合体によってプ ラズマが加熱され，兴の熱エネルギーがコンパクト RFP やスフェロマクと比較して長時間維持されることが示唆さ れた。

〈3. 4〉 STが短寿命な外部 ロイダル磁界の条件 图 3 に示されたように本実験において ST 生成時, $I_{t f c}=10 \sim$ $20[\mathrm{kAT}]$ において極端なプラズマ寿命の減少が観測された。 本節では，この現象について考察を行う。

图 10 に (a) $I_{t f c}<10[\mathrm{kAT}](4.6[\mathrm{kAT}]),(\mathrm{b}) I_{t f c}=10 \sim$ $20[\mathrm{kAT}](10.4[\mathrm{kAT}]),(\mathrm{c}) I_{t f c}>20[\mathrm{kAT}](27.6[\mathrm{kAT}])$, と した場合の ST 合体の樣子をポロイダル磁気面の時間変化

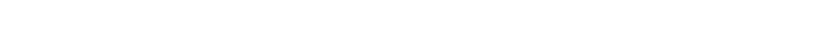
布を同時に示す。ここで示す図 $10(\mathrm{a})$ ～(c) ではスフェロマ ク合体時 $\left(I_{t f c}=0\right)$ に合体する初期配位が左右で同規模にな るようにフラックスコアの入力を調整後 , 固定している。

図 10(b) より，合体前の初期配位が磁気計測範囲に入っ てきた辺りから既に配位の磁気エネルギーが全体的に小 さく，配位の装置中央へ進行する力が弱いことが見てと れる。フラックスコアによって生成された初期配位は，フ ラックスコア $(\mathrm{PF}$ コイル) の反転電流によって弱いなが らも合体し，合体生成配位が形成される。このことから， $I_{t f c}=10 \sim 20[\mathrm{kAT}]$ において合体生成配位が短命である 原因は合体前の段階にあると考えられる。すなわち，初期 プラズマが効率的に生成されていないか，もしくは生成後 合体開始までの間になんらかの不安定で壊れている，とい

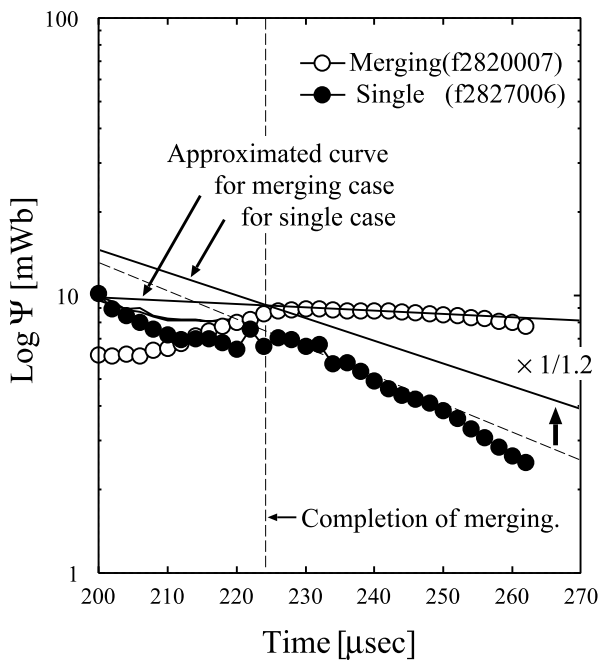

図 9 低 qST の単体および合体時の $\Psi$ の減衰率 の比較 $\left(I_{t f c}=4.6[\mathrm{kAT}]\right)$

Fig. 9. Comparison of $\Psi$ decay rate between single and merging ST with low-q value $\left(I_{t f c}=4.6[\mathrm{kAT}]\right)$.

\section{う 2 通りの場合が予想される。}

図 3 ，図 10 より，この現象は単体生成か合体生成かに はよらないことがわかった。また外部トロイダル磁界が関 係する不安定としては $\mathrm{q}=1$ 不安定が予想される。乥こで 合体効果の生じない単体生成について $I_{t f c}<10[\mathrm{kAT}]$, $I_{t f c}=10 \sim 20[\mathrm{kAT}], I_{t f c}>20[\mathrm{kAT}]$ の3つの条件によ る $\mathrm{q}$ 分布の比較を行った。この結果を図 11 に示す。図中， $I_{t f c}<10[\mathrm{kAT}]$ の条件で生成したプラズマの q 分布を黑， $I_{t f c}=10 \sim 20[\mathrm{kAT}]$ の場合を青， $I_{t f c}>20[\mathrm{kAT}]$ の場合

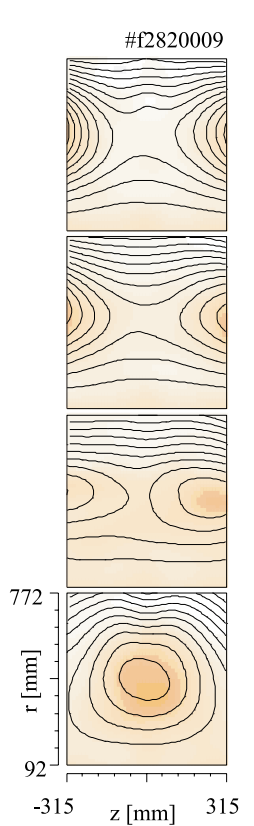

(a) $\mathrm{Itfc}=4.6 \mathrm{kAT}$
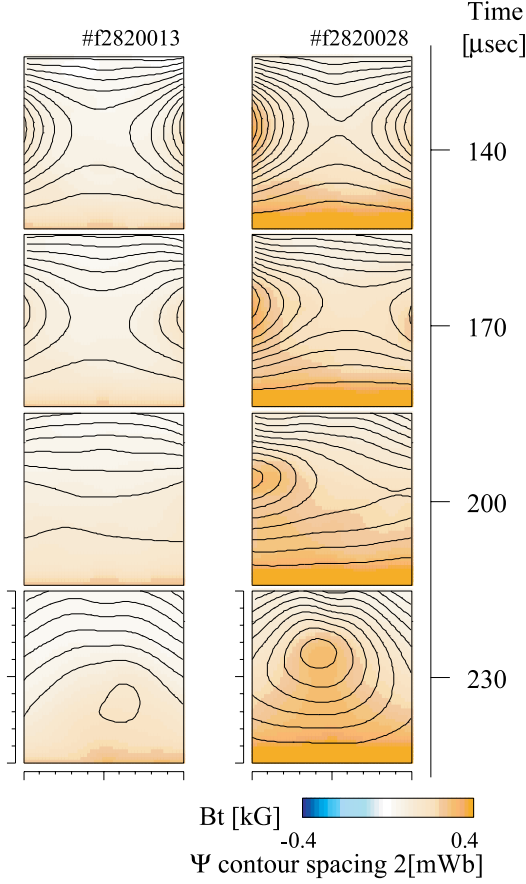

$\begin{array}{ll}\text { (b) } \mathrm{Itfc}=10.4 \mathrm{kAT} & \text { (c) } \mathrm{Itfc}=27.6 \mathrm{kAT}\end{array}$
図 10 樣々な外部卜ロイダル磁界中における ST の生成

Fig. 10. ST formations in varied external toroidal fields.

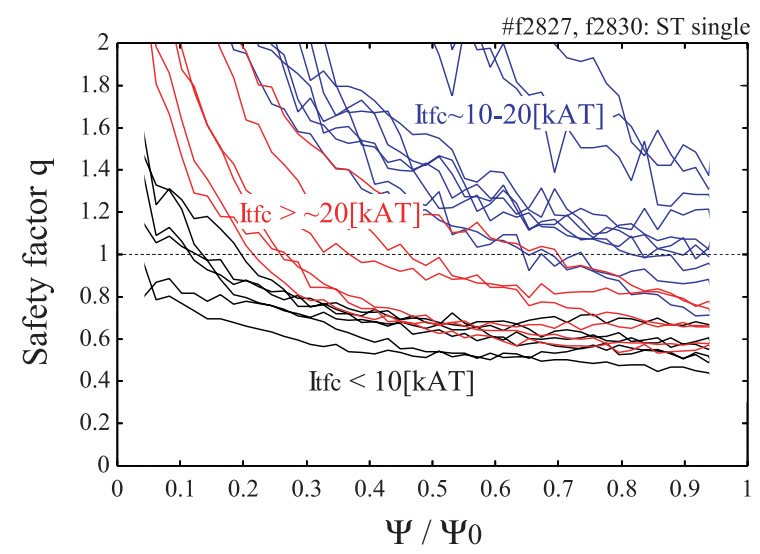

図 11 外部卜ロイダル磁界による q 值の変化 (単体生成 ST)

Fig. 11. Dependence of q-value on external toroidal field (single ST). 
を赤で示す。

図 11 より $I_{t f c}=10 \sim 20[\mathrm{kAT}]$ の場合では極端に $\Psi$ が 減少するために外部卜ロイダル磁界の影響が相対的に強く なり，q 值が全体的に $I_{t f c}<10[\mathrm{kAT}]$ の場合と比較して突 然高くなることがわかる。光して $I_{t f c}>20[\mathrm{kAT}]$ となると 再びプラズマの内部磁束が増加するため q 值が全体的に減 少する。しかし，現時点の磁気プローブ計測領域は図 2(a) に示すように装置中央部のみであり，この現象の原因とな るフラックスコア周辺部を計測することはできない。この ためこの急激なプラズマ寿命の減少の原因を突き止めるに は至らなかった。しかし再び図 10 における左右から進行 してくる合体前の二つのプラズマを見てみると，(a)では 右側のプラズマのトロイダル磁界が左側に比べ強いのに対 し，(c)では炎の逆となる。二つのフラックスコアは独立し た電源で駆動されるため，生成されるプラズマは左右で多 少 $\mathrm{q}$ 分布が異なることを考え合わせると，外部卜ロイダル 磁界すなわち $I_{t f c}$ の值について狭い範囲でこの現象は起こ ると推測される。

\section{4. まとめ}

各種球状トーラスに対する同極性合体の効果について磁 気計測を中心に実験的検証を行った。

その結果まず, テーラー平衡配位であるコンパクト RFP およびスフェロマクでは，初期には軸対称合体効果による 選択的な $\Phi$ の増加, 乥して钅の後, 軸対称合体では予想さ れない $\Psi$ の増加が観測された。また， $\Psi$ 増加時には $\mathrm{n}=2$ トロイダルモードの増加が見られ，同モードがこの場合の 主要な磁束変換機構の原因であると考えられる。合体生成 配位は最終的には再び新たなテーラー平衡状態へと緩和し た。このことから，合体によって平衡からずれた状態がま ず形成され，光れから再びテーラー平衡へとテーラー緩和 が起り，配位は崩壊することなく肥大化し，維持されるこ とが確認された。

次に外部トロイダル磁界が強い ST の場合においては磁 界構造の変化の面において合体効果は比較的小さく，特定 のトロイダルモードの増加も観測されなかった。また，光 の $\lambda$ 実測值である $\lambda_{p}$ の分布からテーラー平衡ではなく， $\lambda_{p} \propto \Psi$ となる特殊な配位へと緩和していることが確認さ れた。

一方，外部卜ロイダル磁界が弱いST 場合では単体生成 された配位は $\lambda_{p}$ の分布からテーラー平衡に近い状態である ことがわかった。しかし，合体生成時には過乘な $\Phi$ にっ て外部トロイダル磁界が強い領域における $\lambda_{p}$ 分布に近づ き，光れが炎のまま維持される。

一般に ST の場合，磁界構造に関する合体効果は小さい。 しかし，単体生成時と合体生成時の $\Psi$ の減衰率の違いから 合体による電子温度上昇効果が推察される。

また，本実験範囲において比較的外部卜ロイダル磁界の 弱い生成条件 $I_{t f c}=10 \sim 20[\mathrm{kA}]$ では ST を効率的に生成 できないことを発見した。本実験では原因解明までは至ら
なかったがフラックスコアによる誘導生成というプラズマ 生成法特有の現象である可能性を示唆した。

(平成 15 年 5 月 6 日受付，平成 15 年 8 月 21 日再受付)

\section{文献}

( 1 ) T. Sato, Y. Oda, S. Otsuka, K. Katayama, and M. Katsurai: Phys. Fluids, Vol.26, p.3602 (1983)

( 2 ) Y.Ono, M.Inomoto, T.Okazaki, and Y.Ueda: Phys. Plasmas, Vol.4, p.1953 (1997)

( 3 ) M. Yamada, H.P.Furth, W.Hsu, A.Janos, S.Jardin, M. Okabayashi, J.Sinnis, T.H.Stix, and K.Yamazaki: Phys. Rev. Lett., Vol.46, p.188 (1981)

(4) M.Tsuruda, Y.Ono, and M.Katsurai: T.IEE Japan, Vol.122A, No.9, pp.840-848 (2002-9) (in Japanese)

鶴田薊子・小野 靖·桂井 誠：電学論 A, 122, 9, pp.840-848 (2002-9)

( 5 ) M.Tsuruda and M.Katsurai: IEEJ Trans. FM, Vol.123, No.4, pp.338-345 (2003-4) (in Japanese) 鶴田藏子 ·桂井 誠 : 電学論 A , 123, 4, pp.338-345 (2003-4)

( 6 ) Y.L.Ho, D.D.Schnack, P.Nordlund, S.Mazur, H.-E. Satherblom J.Scheffel, and J.R.Drake: Phys. Plasmas, Vol.2, p.3407 (1995)

付 録

一般無力磁界配位とテーラー平衡配位

電磁流体プラズマの力学平衡配位は磁束密度を $\boldsymbol{B}$, 電流 密度を $j$ とするとき

$$
\boldsymbol{j} \times \boldsymbol{B}=\nabla p
$$

ここで $p$ はプラズマ熱圧力であるが，いま光れが無視でき る低ベータ (ベータはプラズマ熱圧力と磁気圧の比 , 低ベー タとは $p \sim 0)$ 配位を対象とすると一般無力磁界配位となり

$$
\boldsymbol{j} \times \boldsymbol{B}=0 .
$$

よって $\lambda$ を比例係数として

$$
j=\lambda \boldsymbol{B}
$$

となるが , ここで $\nabla \cdot \boldsymbol{j}=\nabla \cdot \boldsymbol{B}=0$ より

$$
(\boldsymbol{B} \cdot \nabla) \lambda=0 \text {. }
$$

すなわち $\lambda$ は磁力線方向に変化しない。このことから軸対 称トーラス配位において $\lambda$ は磁気面関数 $\sim$ ポロイダル磁束 $\Psi$ の関数 $\lambda(\Psi)$ となり

$$
\boldsymbol{j} / \boldsymbol{B}=\lambda(\Psi)
$$

この一般無力磁界配位においては本文 (5) 式で定義される $\lambda_{p}$ は磁気面 $\Psi$ の関数となる。

テーラー平衡配位はへリシティ保存下において磁気エネ ルギーを最小とした配位であって $\lambda$ は $\Psi$ によらずプラズ マ内部において一定となる。この場合 $\lambda$ は境界形状と外部 トロイダル磁界の值によって一義的に決定され , 固有值と なる。 
鶴 田荋 子 (正員) 1974 年生。1998 年東京大学工学部電気

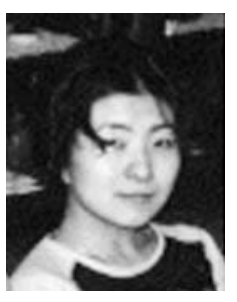

科卒業。2003 年同大学大学院博士課程修了。三 井金属に勤務。

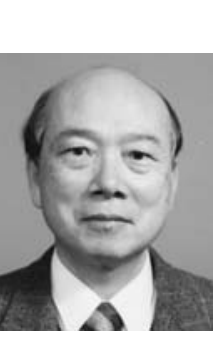

誠（正員）１941 年生。1965 年東京大学工学部電子 科卒業。1970 年同大学大学院博士課程修了。同 年同大学講師，1971 年同助教授，1987 年教授， 現在に至る。主としてプラズマ工学, 核融合工学 の研究に従事。プラズマ・核融合学会。

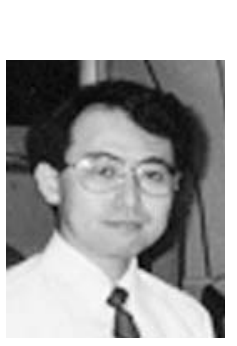

(正員) 1959 年生。1983 年東京大学工学部電気 科卒業。1989 年同大学大学院博士課程修了。同 年同大学助手，1990 年同年同大学講師，1994 年 同助教授，現在に至る。核融合基礎プラズマ実験 に従事。プラズマ・核融合学会, APS 会員。 